\title{
Preliminary Study of the Use of Sulfonated Polyether Ether Ketone (SPEEK) as Proton Exchange Membrane for Microbial Fuel Cell (MFC)
}

\author{
Herlian E. Putra*, Dani Permana*, and Djaenudin \\ ${ }^{a}$ Research Unit for Clean Technology, Indonesian Institute of Sciences, Kampus LIPI Bandung, Jl. Cisitu, Bandung 40135, Indonesia
}

\begin{abstract}
Sulfonated polyether ether ketone (SPEEK) was utilized as a proton exchange membrane (PEM) in Microbial Fuel Cell (MFC). The SPEEK performance in producing electricity had been observed in MFC using wastewater and glucose as substrates. The MFC with catering and tofu wastewater produced maximum power density about $0.31 \mathrm{~mW} / \mathrm{m}^{2}$ and $0.03 \mathrm{~mW} / \mathrm{m}^{2}$, respectively, lower that of MFC with tapioca average power density of $39.4 \mathrm{~W} / \mathrm{m}^{2}$ over $48 \mathrm{~h}$. The power density boosted because of the presence of Saccharomyces cerevisiae as inoculum. The study using of S. cerevisiae and Acetobacter acetii, separately, were also conducted in with glucose as substrate. The MFC produced an average power densities were 7.3 and $6.4 \mathrm{~mW} / \mathrm{m}^{2}$ for $S$. cerevisiae and A. acetii, respectively. The results of this study indicated that SPEEK membrane has the potential usage in MFCs and can substitute the commercial membrane, Nafion.
\end{abstract}

Keywords: Microbial Fuel Cell, sulfonated polyether ether ketone, electricity

Article History: Received: Juni 14 $4^{\text {th }}$ 2017; Received: Sept 25 th 2017; Accepted: December $16^{\text {th }}$ 2017; Available online

How to Cite This Article: Putra, H.E., Permana, D and Djaenudin, D. (2018) Preliminary Study of the Use of Sulfonated Polyether Ether Ketone (SPEEK) as Proton Exchange Membrane for Microbial Fuel Cell (MFC). International Journal of Renewable Energy Development, 7(1), 7-12.

https://doi.org/10.14710/ijred.7.1.7-12

\section{Introduction}

Hydrogen or electricity could be one of the main components in $\mathrm{CO}_{2}$ reduction efforts. Nowadays, as we know, the issues linked to the reduction of global $\mathrm{CO}_{2}$ emissions have been proven able to divert the attention from conventional energy into renewable ones, such as biomass (Metcalf and Eddy, 2003, Notodarmojo, 2005). Hydrogen can be produced not only through Fuel Cell but also biologically through fermentation of saccharide groups at high concentration (Logan et al. 2002, Prestigiacomo et al. 2016) although no more than $50 \%$ of the potential maximum energy that can be generated. Mostly, the resulting energy is derived from advanced fermentation of organic acid such as acetic, butyric, and propionic acid, even solvents also like ethanol and butanol (Logan et al. 2002, Oh et al. 2008)

Beside hydrogen, it is recently known that electricity also can be directly generated from degradation of organic matters in Microbial Fuel Cell (MFC) system (Allen and Benneto, 1993, Katz et al. 2003, Bond and Lovely, 2003, Guerrini et al. 2014).
Some substrates commonly used in MFC are organic wastes (Aborached et al. 2013), pure substrates such as glucose and acetate (Christiani et al. 2013; Gal et al. 2016), domestic wastewater (Permana et al. 2015a; Rahyuningwulan et al. 2015), even from marine sediments (Bond et al. 2002). Meanwhile treating wastewater, MFC capable of generating electricity simultaneously (Santoro et al. 2013).

MFC system generally consists of two chambers, the anode, and cathode. The cathode takes place in aerobic, where the protons generated at the anode with oxygen to form water. At the anode usually lasts for anaerobes, wherein the substrate is oxidized by microbes to generate electricity as the electrons and protons are transferred to the cathode through the proton exchange membrane (PEM), such as membrane and salt bridge (Sukhla et al. 2008, Permana et al. 2013, Singh and Verma, 2015).

PEM is designed to facilitate the transfer of protons from the anode to the cathode while preventing the transfer other substrate and an electron acceptor (oxygen) (Park and Zeikus, 2000, Rabaey et al. 2003).

\footnotetext{
* Corresponding author: dani017@lipi.go.id, her1007@lipi.go.id
} 
Therefore, PEM has an important role in MFC. The using of appropriate PEM can increase the power output of MFC. One of the most popularly used in MFC is Nafion ${ }^{\circledR} 117$ because of its high selective permeability to proton. However, Nafion ${ }^{\circledR} 117$ being expensive, at the end, it will affect the production cost of MFC. PEEK is one of promising polymer to replace Nafion. PEEK is a low-cost polymer which having good thermal stability, mechanical properties (Handayani et al. 2007), and better ionic conductor (Neburchilov et al. 2007). Its proton conductivity can be achieved by sulphonation process.

Since have not been many reports of the using of SPEEK on MFC, in the present study, authors report electricity generation from various substrates comprise wastewater (tapioca, tofu, catering) and pure substrate (glucose) using MFC system. Sulphonated polyether ether ketone (SPEEK) is used as a membrane.

\section{Materials and Methods}

\subsection{Substrates and inoculum sources}

Two kinds of substrates are separately used in this study comprise glucose and wastewater. The first MFC setup, both of Acetobacter aceti and Saccharomyces cerevisiae were carried out in a sterilized nutrient medium $(21,6 \mathrm{mg} / \mathrm{mL}$ glucose, $0.5 \%$ yeast, $0.5 \%$ peptone, $0.3 \% \mathrm{KH}_{2} \mathrm{PO}_{4}$, and $0.3 \%\left(\mathrm{NH}_{4}\right)_{2} \mathrm{SO}_{4}$ at $\mathrm{pH} 7$. These compositions were used as a single of inoculum and as a medium of growth (Permana et al. 2015b). Microbes were inoculated into $25 \mathrm{ml}$ sterile medium and grown at $30^{\circ} \mathrm{C}$ for $18 \mathrm{~h}, 150 \mathrm{rpm}$.

Meanwhile, wastewater was collected and put into a sterile plastic bottle measuring $1 \mathrm{~L}$. It was obtained directly from effluent at tapioca, tofu and catering industry. There was no amended with medium ingredients. It was intended like to be the condition of the waste field and used as the inoculum and growth medium. The initial $\mathrm{pH}$ of all solutions was adjusted to 7 and all MFCs were operated in a temperaturecontrolled room at $30^{\circ} \mathrm{C}$.

\subsection{Experimental setup}

The fabricated MFC consist of two glass chamber (net volume of $900 \mathrm{ml}$ ) separated by SPEEK membrane (Figure 1). MFC system is supported by copper electrodes connected into the outer circuit. The first chamber (anode) is containing wastewater and potassium permanganate $\left(\mathrm{KMnO}_{4}\right)$ solution as an electron acceptor in the other room. The potassium permanganate solution had an average concentration of $50 \mathrm{ppm}$ were conditioned under acidic conditions; the $\mathrm{pH}$ is about 3 to 4 .

\subsection{SPEEK membrane}

Synthesis and characterization of SPEEK have been described in earlier reports (Handayani et al. 2007). In a typical experiment, $5 \mathrm{~g}$ of PEEK powder (450-P, Victrex) was dissolved in $100 \mathrm{ml}$ of sulfuric acid (Merck,
95-97\%). The sulphonated reaction was done during 3 $\mathrm{h}$ at $60^{\circ} \mathrm{C}$. The resulting mixture was poured onto crushed ice and the innumerable fibers that were formed were recovered by filtration. Washing process with deionized water was done several times until the $\mathrm{pH}$ reached neutral. The acquired polymer was dried at $70^{\circ} \mathrm{C}$ for 48 hours.
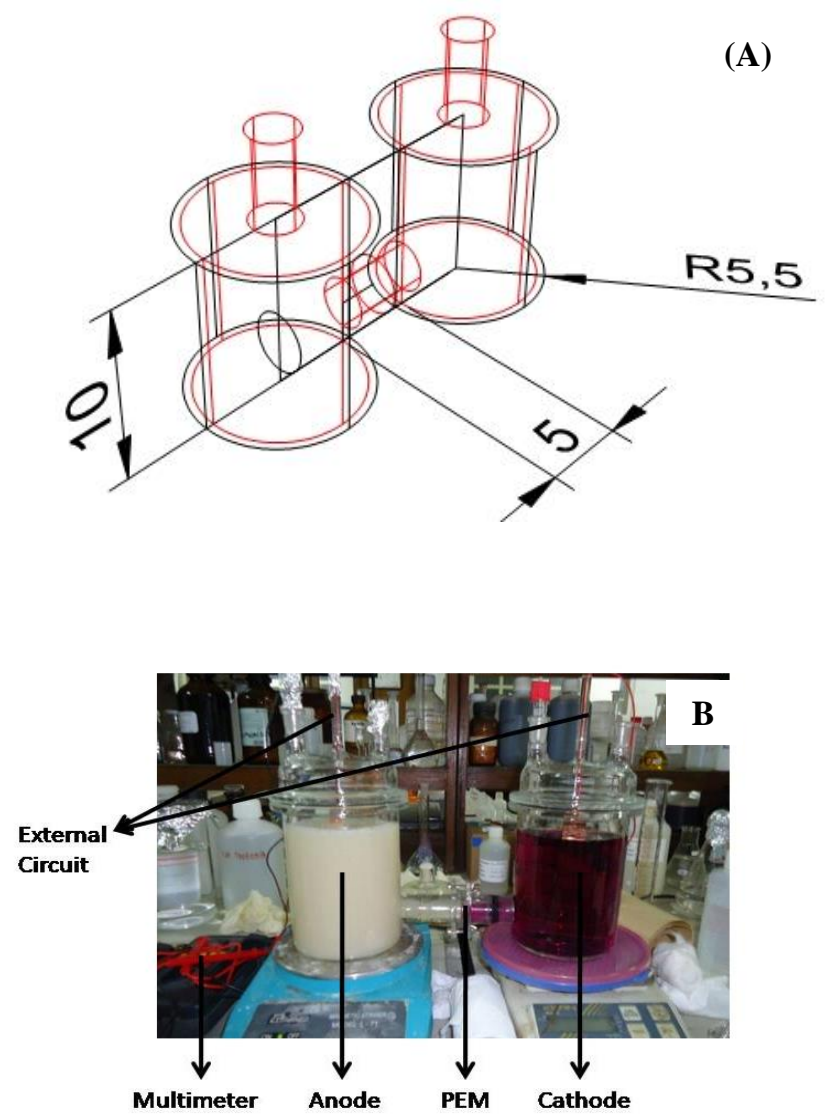

Fig. 1 Schematic of Double Chamber MFC (A). Dual Chamber MFC reactor used in this research that suggested by You et al (2006) and Permana et al. (2013, 2015a). PEM (proton exchange membrane) that used was SPEEK. The volume of each chamber is $1000 \mathrm{~mL}$.

Dried SPEEK was dissolved in n-methyl-2pyrrolidone (composition $12.5 \%$ up to $15 \%$ by weight solution), then allowed to stand overnight. Membrane sonication for 15 minutes was done before its printing using doctor blade (size $850 \mu \mathrm{m}$ ) on the glass plate, then oven-dried. For this study, SPEAK give the value of ion exchange capacity, proton conductivity, and percentage water absorption were $2.1 \mathrm{meq} / \mathrm{g}, 0.045 \mathrm{~S} / \mathrm{cm}$, and $16 \%$ respectively.

\subsection{Methods for Analysis}

The MFC was a closed system. The circuit was completed with fixed load of $1 \mathrm{~K} \Omega$. Both of voltage and current was recorded by using a digital multimeter (Model Sanwa CD800a). Power was also calculated according to this formula, $P=I V$, where, $P(\mathrm{~W})$ is the power, $V(\mathrm{mV})$ is the voltage, $I(\mathrm{~mA})$ is the current, and $R(\Omega)$ is the external resistance. 
The power generated is calculated based on the data of potential and a strong current that is read by a multimeter with equation (1), power density is calculated using equation (2) (Rabaey et al. 2013).

$$
\begin{aligned}
& \mathrm{P}=\mathrm{V} \times \mathrm{I} \\
& \mathrm{Pd}=\mathrm{P} \div \mathrm{A}
\end{aligned}
$$

$$
\begin{array}{ll}
\text { where } & \\
\mathrm{P} & =\text { Power }(\mathrm{mW}) \\
\mathrm{V} & =\text { Potential }(\mathrm{mV}) \\
\mathrm{I} & =\text { Current }(\mathrm{mA}) \\
\mathrm{Pd} & =\text { Power density }\left(\mathrm{mW} / \mathrm{cm}^{2}\right) \\
\mathrm{A} & =\text { Anode surface area }\left(\mathrm{cm}^{2}\right)
\end{array}
$$

The concentration of Chemical Oxygen Demand (COD) from wastewater was also determined (before and after the process) according to Indonesian National Standard SNI 6989.73:2009. The process took 48 hours. The SNI 6989.73:2009 is a standard method for COD analysis that based on the closed reflux titrimetry. Samples oxidized by the strong oxidizer, potassium dichromate $\left(\mathrm{K}_{2} \mathrm{Cr}_{2} \mathrm{O}_{7}\right)$ in the closed tube for 2 hours at $150^{\circ} \mathrm{C}$. The amount of unreacted potassium dichromate then titrated with ferrous ammonium sulfate with feroin as an indicator. The analysis of samples was done with three replicates. The COD analysis methods maintained with the analysis of COD of standard samples, the use of pro analytical chemical reagents, special glassware, calibrated pippets, thermometer, burettes, and balance.

The Atomic Absorption Spectrometry (AAS) (Flame AAS, Hitachi) was used to determine the residue of permanganate ions $\left.\left(\mathrm{MnO}_{4}\right)^{-}\right)$in the catholyte. The reduced permanganate ions are written in percentage (\%).

\section{Results and Discussion}

\subsection{Profile of power density generated from wastewater}

The MFCs with SPEEK membrane and using tofu and catering wastewater have produced a maximum power density of $0.03 \mathrm{~mW} / \mathrm{m}^{2}$ and $0.31 \mathrm{~mW} / \mathrm{m}^{2}$, respectively (Fig. 2). These values were very low because of mixture culture without any additional treatment.

Among of wastewater, electricity production showed that the greatest was tapioca wastewater. The MFC with tapioca wastewater achieved an average power density of $114 \mathrm{~mW} / \mathrm{m}^{2}$ over $16 \mathrm{~h}$ (6-20h) (Fig. 3). This level of average power generation was almost three times to that obtained using Geobacter metallireducens in the MFC reactor with Nafion and cereal wastewater as membrane and substrate around $38 \mathrm{~mW} / \mathrm{m}^{2}$ over $71 \mathrm{~h}$. The maximum voltage reached about $666 \mathrm{mV}$ higher than $400 \mathrm{mV}$ which produced by MFC with SPEEK utilizing both dairy wastewater and domestic wastewater.

Power generation has increased since adding 0.025 ppm of $S$. cerevisiae as inoculum. This yeast concentration had greatly affected the value of the generated voltage, more number of yeast cells the more the metabolic processes can take place.

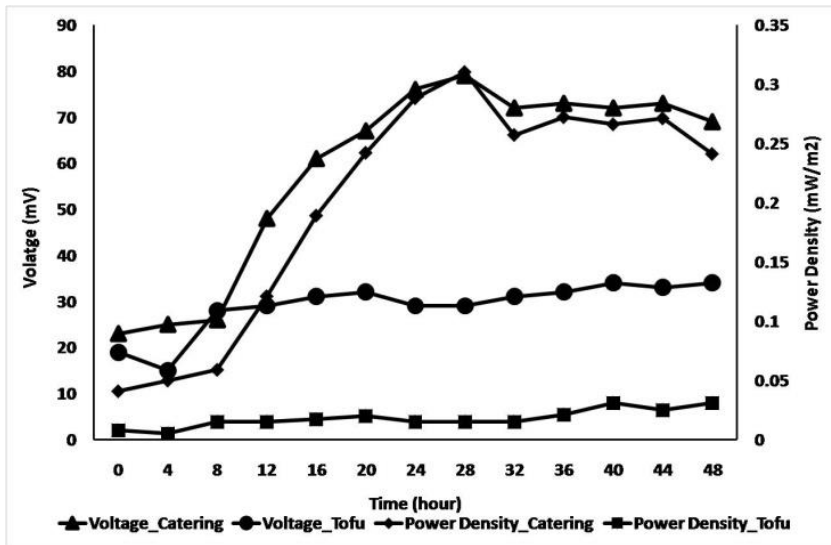

Fig. 2 Voltage and Power Density in MFC Using Tofu and Catering Wastewater

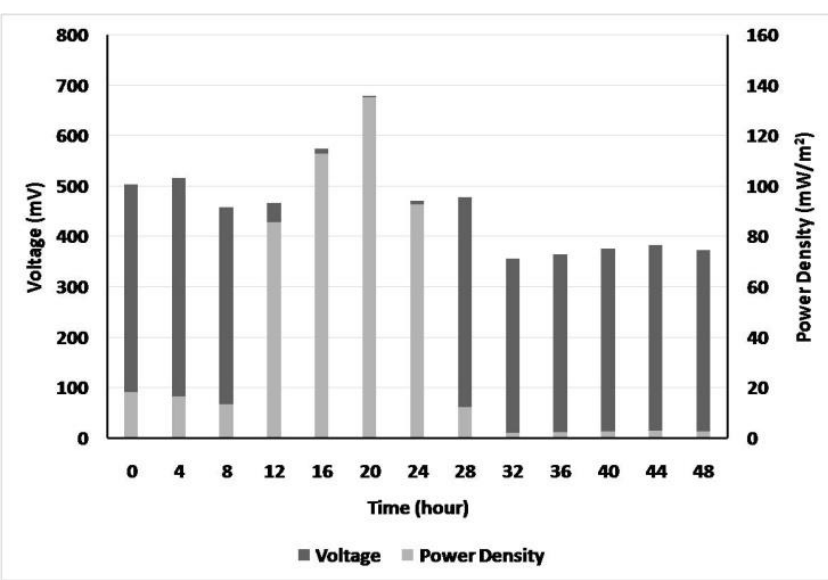

Fig. 3. Voltage and Power Density in MFC Using Tapioca Wastewater

\subsection{Profile of power density generated from glucose}

The MFCs with SPEEK membrane was also applied with glucose as a medium of growth for selected microbes; $A$. aceti and $S$. cerevisiae. Though these microbes are commonly used in the fermentation process, the process set at the semi-aerobic condition.

In the present study, glucose was also used as a substrate for the MFC. S. cerevisiae and A. acetii were used as biocatalysts in the MFCs used glucose as substrate and carbon source in the anode chamber and generate electrons and protons $\left(\mathrm{H}^{+}\right)$. A total of 24 mol electrons and hydrogen ions were produced by oxidation of one mole of glucose in the anaerobic condition. The anodic reaction is taken place at the anode as summarized in equation (3).

$$
\mathrm{C}_{6} \mathrm{H}_{12} \mathrm{O}_{6}+6 \mathrm{H}_{2} \mathrm{O} \rightarrow 6 \mathrm{CO}_{2}+24 \mathrm{e}^{-}+24 \mathrm{H}^{+}
$$

The electron produced by microorganism and captured by anode surfaces and protons $(\mathrm{H}+)$ travel through SPEEK and react with oxygen in the cathode to produce water $\left(\mathrm{H}_{2} \mathrm{O}\right)$. Electrons from anode then 
captured by permanganate ions (MnO4-) that play a role as an electron acceptor that captured electrons that traveled from the anode. Permanganate ion was used as electron acceptor because it has high oxidization capacity and also more environmentally friendly (nondangerous reduced products). Either in acidic and alkaline conditions, permanganate ion accepts three electrons and reduced to manganese dioxide, as shown in equations (4) and (5).

$$
\begin{array}{ll}
\mathrm{MnO}_{4}^{-}+4 \mathrm{H}^{+}+3 \mathrm{e}^{-} \rightarrow \mathrm{MnO}_{2}+2 \mathrm{H}_{2} \mathrm{O}, & E^{\circ}=1.70 \mathrm{~V} \\
\mathrm{MnO}_{4}^{-}+2 \mathrm{H}_{2} \mathrm{O}+3 \mathrm{e}^{-} \rightarrow \mathrm{MnO}_{2}+4 \mathrm{OH}^{-}, & E^{\circ}=0.59 \mathrm{~V}
\end{array}
$$

Equations (4) and (5) explained that permanganate ion has higher potential in acidic condition. Therefore in the present study, the acidic condition was used for the cathodic electron acceptor expecting to maximize the electricity generation (Permana et al. 2015b).

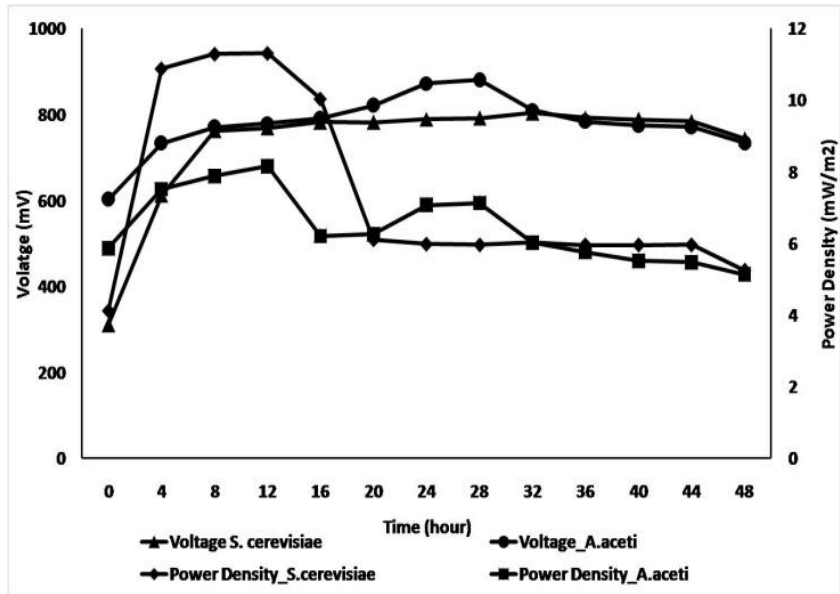

Fig. 4 Voltage and power density in MFC using glucose and selected microbes

During the process, the voltages kept elevated until 28 hours and tend to decrease afterward since glucose concentration has also diminished. Separately, the MFC using $A$. aceti shown that the maximum voltage was about $880 \mathrm{mV}$ (after the $28 \mathrm{~h}$ process) larger than $803 \mathrm{mV}$ (after the $32 \mathrm{~h}$ process) using $S$. cerevisiae (Figure 4). The average power density was higher around $6.4-7.3 \mathrm{~mW} / \mathrm{m}^{2}$ compared to $0.7 \mathrm{~mW} / \mathrm{cm}^{2}$ of maximum power density generated from one chamber air cathode MFC (Permana et al. 2015b).

The value of voltage and electricity current greatly dependent on substrate supply that used as oxidation medium for biocatalyst (Liu and Li, 2013, Li et al. 2014, Kim et al. 2015). Although the resulting voltage larger, a higher internal resistance on the system have resulted in small electricity current (data not shown) compared to Walker and Walker Jr's (Walker and Walker 2006). Double chamber MFC usually have large internal resistance (Permana et al. 2013; 2015a). Moreover, oxygen existed in system inhibited electron transport from the anode into the cathode. The electrons were more prone to the process of reduction in aerobic condition (Abourached et al. 2013).

\subsection{Profile of COD level after process}

In this study, the tofu, catering, and tapioca wastewater were used to demonstrate electricity generation in a two-chambered MFC. Following startup and $48 \mathrm{~h}$ process, the total COD of each wastewater was measured. COD level was significantly decreased for tapioca wastewater almost $97 \%$ in 2 days after MFC operated (Table 1).

Table 1.

COD Removal.

\begin{tabular}{lcccc}
\hline $\begin{array}{c}\text { Wastewater } \\
\text { (COD in ppm) }\end{array}$ & \multicolumn{3}{c}{ MFC Process (hours) } & $\begin{array}{c}\text { Percentage } \\
\text { of COD } \\
\text { Removal }\end{array}$ \\
\cline { 2 - 5 } & $\mathbf{0}$ & $\mathbf{2 4}$ & $\mathbf{4 8}$ & 96.80 \\
Tapioca & 2000 & 96 & 64 & 36.00 \\
Tofu & 6750 & 6300 & 4320 & 41.08 \\
Catering & 18,840 & 13,800 & 11,100 & \\
\hline
\end{tabular}

MFC is a bioelectrochemical system that drives a current by mimicking bacterial interactions. Not only used for generating electricity, it also can be used for wastewater treatment. These results showed that organic substances concentration was decreased during 48 hours of the experiment. It was used by $S$. cerevisiae and Acetobacter acetii as a carbon source for growth and production of ethanol by the yeast, $S$. cerevisiae. The electrons produced as another output for electricity generation (Permana et al. 2015b).

\subsection{Concentration of electrons acceptor}

Permanganate ions $\left(\mathrm{MnO}^{4-}\right)$ used as catholyte because it has manganese $(\mathrm{Mn})$ atom with +7 of the oxidation number. It able to accept many electrons, although it caused its oxidation number reduced to +4 or +2 to form manganese oxide, $\mathrm{MnO}_{2}$ or $\mathrm{MnO}$. The initial concentration of permanganate ions was $50 \pm 0.4 \mathrm{ppm}$. After MFC process finished for 48 hours the concentration dropped to $3.02 \pm 0.1 \mathrm{ppm}$ or $93.90 \%$ of manganese reduced. This results confirmed that $\mathrm{Mn}$ atoms successfully reduced by the electrons that produced in MFC. Manganese reduced and formed a black-brown sediment of $\mathrm{MnO}_{2}$ or $\mathrm{MnO}$ in the cathode chamber (Fig. 5).
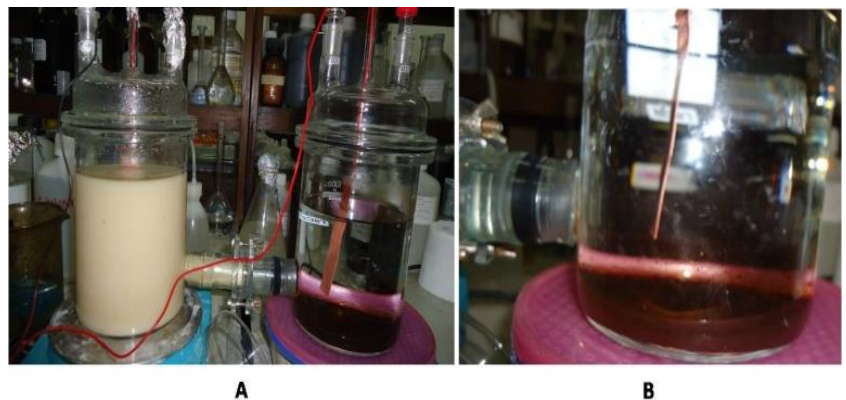

Fig. 5 The color of catholyte changed after 48 hours and concentration of manganese decreased (A). The formation of black-brown sediment of $\mathrm{MnO}_{2}$ or $\mathrm{MnO}$ in the cathode. 
The manganese also released two or three oxygen atoms when it reduced and formed manganese oxide $\left(\mathrm{MnO}_{2}\right.$ or $\left.\mathrm{MnO}\right)$. The oxygen atoms then reacted with proton that permeates through SPEEK from the anode to form water molecules. We suggested that the concentration of free proton that entered into cathode was very low. Because protons directly reacted with oxygens. It was indicated by there is no significant $\mathrm{pH}$ change in catholyte.

\section{Conclusion}

The SPEEK membrane has the potential usage in MFC as proton exchange membrane. It is efficient and a cheap alternate the commercial membrane, Nafion ${ }^{\circledR}$. It is also suitable to be applied for MFC with various substrates, for example, glucose and other wastewater. The MFC with catering and tofu wastewater generated maximum power density of $0.31 \mathrm{~mW} / \mathrm{m}^{2}$ and 0.03 $\mathrm{mW} / \mathrm{m}^{2}$, respectively, lower than $\mathrm{MFC}$ with tapioca at the average power density of $39.4 \mathrm{~W} / \mathrm{m}^{2}$ over 48 hours. The power density boosted because of the presence of $S$. cerevisiae as inoculum. The study using of $S$. cerevisiae and Acetobacter acetii, separately, were also conducted in with glucose as substrate. The MFC produced an average power densities were 7.3 and 6.4 $\mathrm{mW} / \mathrm{m}^{2}$ for $S$. cerevisiae and $A$. acetii, respectively

\section{Acknowledgments}

Authors want to thank you to DIPA of Research Unit for Clean Technology for funding and equipment support. Also thank to Mahyar Ependi and Oman Rohman for sampling and analysis support.

\section{References}

Abourached, C., Catal, T., Liu, H. (2013) Efficacy of singlechamber microbial fuel cells for removal of cadmium and zinc with simultaneous electricity production. Water Research, 51, 228-233.

Bond, D. R. \& Lovely. D. R. (2003) Electricity production by Geobacter sulfureducens attached to electrodes. App. Environ. Microbiology. 69, 1548-1555.

Cristiani,P., Carvalho, M. L., Guerrini, E., Daghio, M., Santoro, C. Li, B. (2013) Cathodic and anodic biofilms in Single Chamber Microbial Fuel Cells. Bioelectrochemistry 92, 6-13.

Gal, I., Schlesinger,O., Amir, L., Alfonta, L. (2016) Bioelectrochemistry Yeast surface display of dehydrogenases in microbial fuel-cells. Bioelectrochemistry, 112, 53-60.

Guerrini, E., Grattieri, M., Trasatti, S. P., Bestetti, M., Cristiani, P. (2014) Performance explorations of single chamber microbial fuel cells by using various microelectrodes applied to biocathodes. International Journal of Hydrogen Energy, 39(36), 21837-21846.

Handayani, S., Purwanto, W.W., Dewi, E.L., Soemanto,R.W. (2007) Synthesis and characterization of electrolyte membranes sulfonated poly ether ether ketone. Indonesian Journal of Materials Science. 8(2), 129-133.

Katz, E., Shipway, A.N. \& Willner. I. (2003) Biochemical fuel cell.In Handbook of Fuel Cells-Fundamental, Technology and Applications, Vol.I: Fundamental and Survey of
Systems.W. Vielstich, H. A. Gasteiger and A. Lamm.Wiley and Sons, Ltd. New York.

Kim, H., Kim, B. and Yu, J. (2015) Bioresource Technology Power generation response to readily biodegradable COD in singlechamber microbial fuel cells. Bioresource Technology, 186, 136-140.

Li, Y., Wu, Y., Puranik, S., Lei, Y., Vadas, T., Li, B. (2014) Metals as electron acceptors in single-chamber microbial fuel cells. Journal of Power Sources, v269, 430-439.

Liu, B. and Li, B. (2013) Single chamber microbial fuel cells ( SCMFCs ) treating wastewater containing methanol. International Journal of Hydrogen Energy, 39(5), 23402344.

Logan, B. E., Oh, S. E., Kim, I. S., Van Ginkel, S. (2002) Biological hydrogen production measured in batch anaerobic respirometers. Environ. Sci. Tech., 36, 2530-2535.

Logan, B. E. (2004) Feature article: biologically extracting energy from wastewater: biohydrogen and microbial fuel cells. Environ. Sci. Tech., 38(9), 160A-167A.

Metcalf \& Eddy. (2003) Wastewater Engineering, Treatment and Reuse. Fourth edition. New York: McGraw-Hill.

Neburchilov, V.; Martin, J.; Wang, H.; Zhang. J. (2007) Review of Polymer Electrolyte Membranes for Direct Methanol Fuel Cells. J. Power Sources. 169, 221-238.

Notodarmojo, S. (2005) Pencemaran Tanah dan Air Tanah. Penerbit: ITB.

Oh, S. E., Min, B., Logan, B.E. (2008) Cathode performance as a factor in electricity generation in microbial fuel cells. Environ. Sci. Technology. 38, 4900-4904.

Park, D.Y. and Zeikus, J.G. (2000) Electricity generation in microbial fuel cells using neutral red as an electronophore, Applied and Environmental Microbiology, 66, 1292 - 1297.

Permana, D. H. R. Haryadi, H. E. Putra, W. Juniaty, S. D. Rachman, dan S. Ishmayana. (2013) Evaluasi penggunaan Metilen Biru Sebagai Mediator Elektron pada Microbial Fuel Cell dengan Biokatalis Acetobacter aceti. Molekul, Journal of Chemistry. 8(1), $78-88$.

Permana, D. H. E. Putra, Djaenudin, D. Rahayuningwulan, H. R. Hariyadi. (2015a) Electricity Generation from Tapioca Wastewater Using Double Chamber Microbial Fuel Cell (DCMFC) with Saccharomyces cerevisiae as Biocatalysts Source. The $4^{\text {th }}$ International Conference on Fuel Cell and Hydrogen Technology 2013. Yogyakarta 7-10 October 2013. ISBN 978-602-95555-7-8. 34-27.

Permana, D., Rosdianti, D., Ishmayana, S., Saadah,D., Rachman, D., Putra, H.E., Rahayuningwulan, D. and Hariyadi,H.R. (2015b) Preliminary Investigation of Electricity Production Using Dual Chamber Microbial Fuel Cell (DCMFC) with Saccharomyces cerevisiae as Biocatalyst and Methylene Blue as Electron Mediator. Procedia Chemistry. 17, 36-43.

Prestigiacomo, C., Fernandez-marchante, C. M., Fernándezmorales, F. J., Cañizares, P. and Scialdone, O. (2016) New prototypes for the isolation of the anodic chambers in microbial fuel cells. Fuel, 181, 704-710.

Putra, H.E., D. Permana, A. S. Putra, Djaenudin, H. R. Hariyadi. (2012) Utilization of Microbial Fuel Cell for Electricity Generation from Wastewater of Food Industry. Indonesian Journal of Applied Chemistry. 14, $78-82$.

Rabaey, K., Lissens, G.,Siciliano, S.D. and Verstraete. W. (2003) A microbial fuel cell capable of converting glucose to electricity at high rate and efficiency, Biotechnology Letters, $25,1531-1535$.

Rahayuningwulan, D. Permana, D., Utami, R.P. (2013) The Influence of Electrode Configuration in Single Chamber Microbial Fuel Cell Using Rice-rinsing Wastewater as Substrate. The $4^{\text {th }}$ International Conference on Fuel Cell and Hydrogen Technology 2013. Yogyakarta 7 - 10 October 2013. ISBN 978-602-95555-7-8. 47-50.

Santoro, C., I. Ieropoulos, J. Greenman, P. Cristiani, T. Vadas, A. Mackay, and B. Li. (2013) Current generation in 
Citation: Putra, H.E., Permana, D and Djaenudin, D. (2018) Preliminary Study of the Use of Sulfonated Polyether Ether Ketone (SPEEK) as Proton Exchange Membrane for Microbial Fuel Cell (MFC). Int. Journal of Renewable Energy Development, 7(1), 7-12, doi.org/10.14710/ijred.7.1.7-12

$\mathrm{P}$ a g e | 12

membraneless single chamber microbial fuel cells (MFCs) treating urine. Journal of Power Sources, 238, 190-196.

Schröder, U. (2007) Anodic electron transfer mechanisms in microbial fuel cell and their energy efficiency, Physical Chemistry Chemical Physics, 9, 2619 - 2629.

Shukla, A.K., Suresh, P., Berchmans, S. and Rajendran, A.(2004) Biological fuel cells and their applications, Current Science, $87,455-468$.

Singh, S., Modi, A., and Verma, N. (2015) Enhanced power generation using a novel membrane-less single chamber microbial fuel cell. International Journal of Hydrogen Energy, 41(2), 1237-1247.
You, S., Zhao, Q., Zhang, J., Jiang, J., Zhao, S. (2007) A microbial fuel cell using permanganate as the cathodic electron acceptor. Journal of Power Sources. 162, 1409-1415

SNI 6989.72:2009. Cara uji Kebutuhan Oksigen Biokimia (Biochemical Oxygen Demand/BOD).

SNI 6989.73:2009. Cara uji Chemical Oxygen Demand (COD)

SNI 06-6989.11-2004.Cara uji derajat keasaman (pH)

SNI 6989.59:2008. Teknik Pengambilan Sampel 